Advances in Gene Technology: The Genome and Beyond -

Structural Biology for Medicine (Proceedings of the 2002

Miami Nature Biotechnology Winter Symposium)

TheScientificWorld 2002, 2(S2), 123-124

ISSN 1532-2246; DOI 10.1100/tsw.2002.58

\title{
HYPOXIA-INDUCIBLE FACTOR-1 (HIF-1) IN EXPERIMENTAL BRAIN ISCHEMIA
}

\author{
$\underline{\text { Rainald Schmidt-Kastner }}^{*}$,1, Bao-Tong Zhang ${ }^{1}$, Keith Webster ${ }^{2}$, Thomas Kietzmann ${ }^{3}$, \\ Weizhao Zhao ${ }^{1}$, Raul Busto ${ }^{1}$, and Myron D. Ginsberg ${ }^{1}$ \\ ${ }^{1}$ Deptartments. of Neurology and ${ }^{2}$ Mol. Cell. Pharmacology, University of Miami School \\ of Medicine, P.O. Box 016960, Miami, FL 33101; ${ }^{3}$ Inst. Biochem. Mol. Cell Biol., Univ. \\ Göttingen, Germany \\ *Rainald@stroke.med.miami.edu
}

INTRODUCTION. Recently, a specific defense system against hypoxia has been described which uses the hypoxia-inducible factor-1 (HIF-1) as transcription factor. HIF1 coordinates the response to prolonged hypoxia which pertains to glycolysis (e.g., lactate dehydrogenase $=\mathrm{LDH}-5$ ), glucose transport, vasodilation, and angiogenesis[1]. The level of the HIF- $1 \alpha$ subunit is oxygen-dependent, and the protein concentration is mainly regulated via degradation in the proteasome[1], involving a novel class of oxygen-sensing proline-4-hydroxylases[2]. HIF-1 $\alpha$ combines with the constitutively expressed HIF-1 $\beta$ protein to form HIF-1[1]. Ischemia and hypoxia of the brain are major events in cardiac arrest and stroke. In this report, we examined changes of HIF-1 $\alpha$ mRNA and the target gene, LDH-5, in the forebrain of rats after transient global brain ischemia[3] or in chronic oligemia[4].

METHOD. Global brain ischemia was induced in halothane-anesthetized, normothermic Wistar rats by using two-vessel occlusion and hypotension for $12.5 \mathrm{~min}$. The recirculation periods were $30 \mathrm{~min}, 1,3,6 \mathrm{~h}$, and $1,2,3$, and 7 days $(\mathrm{n}=2-5)$. To induce chronic oligemia, permanent bilateral common carotid artery occlusion (BCCAO) was used in Wistar rats for $1 \mathrm{~h}, 6 \mathrm{~h}, 1$ day, and 7 days $(\mathrm{n}=4-5)$. Rat-specific polyclonal antibodies for HIF-1 $\alpha$ were used in immunohistochemistry[5] on vibratome sections of $4 \%$ paraformaldehyde-fixed brains. In situ hybridization was carried out using radioactive, rat-specific antisense probes to HIF-1 $\alpha$ mRNA and LDH-5 mRNA[6], followed by quantitative film autoradiography.

RESULTS. Using a rat-HIF-1 $\alpha$ specific polyclonal antiserum in immunohistochemical studies on control rat brains, we obtained generalized neuronal labelling in forebrain regions; astrocytes or vessels were unreactive. In parallel, in situ hybridization showed widespread expression of HIF- $1 \alpha$ mRNA in control brains. HIF-1 $\alpha$ mRNA was increased in CA1 at 1 day after global ischemia (optical density $=197 \pm 14 \%$ of control; ANOVA, $p<0.05$ ) but not at earlier time points. The increased signal was clearly localized to the vulnerable CA1 neuronal layer in emulsion-coated sections. HIF-1 $\alpha$-like immunoreactivity slightly decreased in CA1 by 1 day, and then disappeared at 3 and 7 
days due to cell death. No increase in HIF-1 $\alpha$ mRNA or LDH-5 mRNA was found in regions with reactive glial changes. By contrast, a rapid and widespread increase of HSP70 mRNA was noted in the forebrain between 30 min and 1 day after global brain ischemia. In the oligemia model, constant levels of HIF-1 $\alpha$ mRNA were observed, whereas LDH-5 mRNA was upregulated in the neocortex at 1 day with a columnar pattern.

DISCUSSION. Our study indicates that HIF- $1 \alpha$ is constitutively expressed in forebrain neurons, implying that neurons can perform immediate regulatory responses to hypoxia and ischemia. The presently used HIF-1 $\alpha$ antibodies indicate a high expression level in neurons, while detection of active or degraded forms of HIF-1 $\alpha$ remains to be defined. Upregulation of HIF- $1 \alpha$ mRNA occurred at 1 day of recirculation, and it was limited to the vulnerable CA1 neurons that are bound to die by 2-3 days after ischemia. Thus, HIF1 regulation differs from a typical stress response gene such as HSP70 that is expressed early after ischemia and in a widespread fashion. It remains to be determined whether an additional hypoxic situation preceded cell death in CA1 neurons and whether changes in HIF-1 $\alpha$ mRNA are in reaction to a consumption of HIF-1 protein. Oligemia per se affected the HIF-1 target gene, LDH-5, suggesting that hypoxia prevailed in the chronic carotid occlusion model.

ACKNOWLEDGEMENT. Supported by NS05820.

\section{REFERENCES}

1. Semenza, G.L. (1998) Curr. Opin. Genet. Dev. 8, 588-594.

2. $\quad$ Epstein, A.C.R. et al. (2001) Cell 107, 43-54.

3. Schmidt-Kastner, R., Fliss, H., and Hakim, A.M. (1997) Stroke 28, 163170.

4. Schmidt-Kastner, R., Truettner, J., Lin, B., Zhao, W., Saul, I., Busto, R., and Ginsberg, M.D. (2001) Mol. Brain Res. 92, 157-166.

5. Kietzmann, T., Roth, U., and Jungermann, K. (1999) Blood 94, 4177-4185.

6. Webster, K. (1987) Mol. Cell. Biochem. 77, 19-28. 


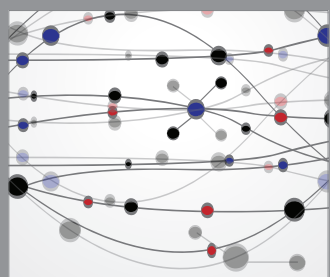

The Scientific World Journal
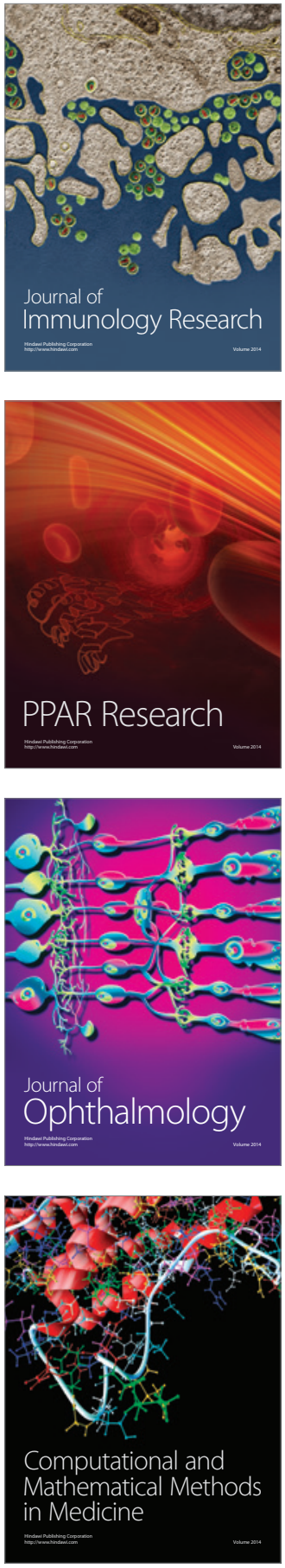

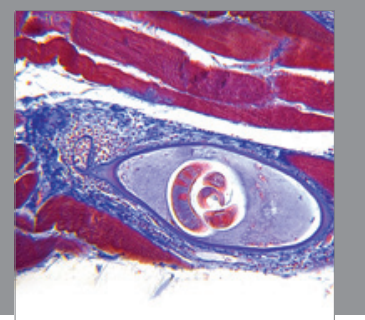

Gastroenterology

Research and Practice
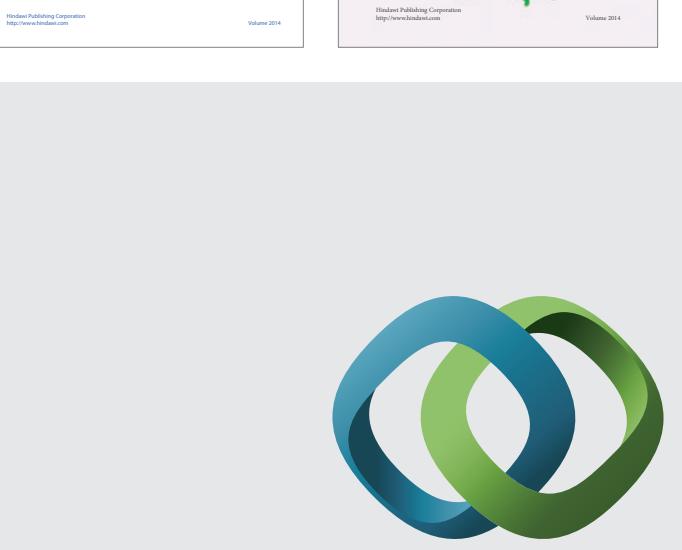

\section{Hindawi}

Submit your manuscripts at

http://www.hindawi.com
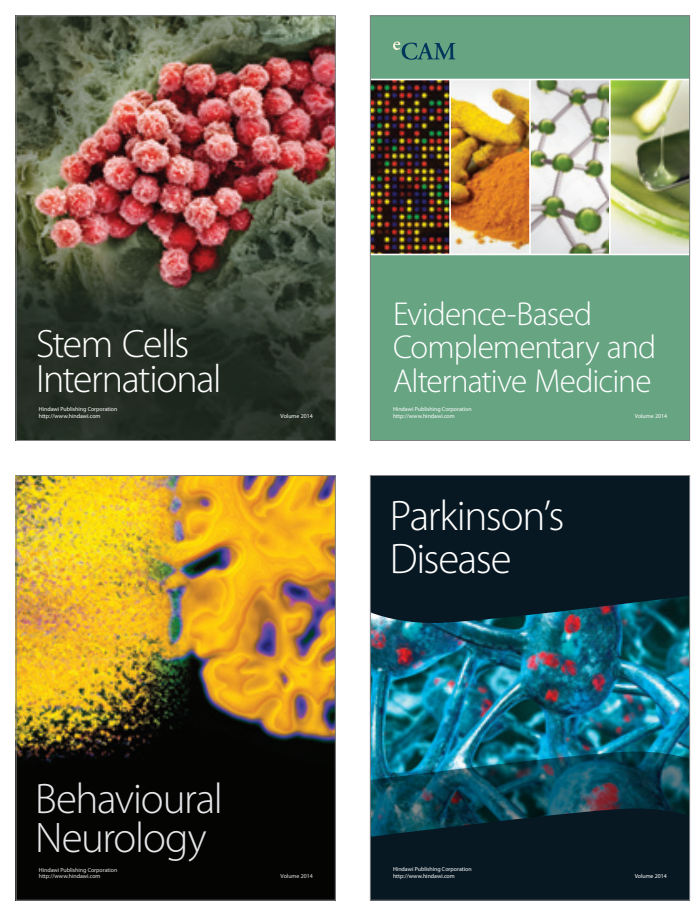

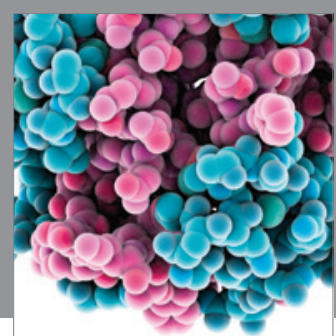

Journal of
Diabetes Research

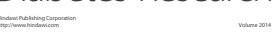

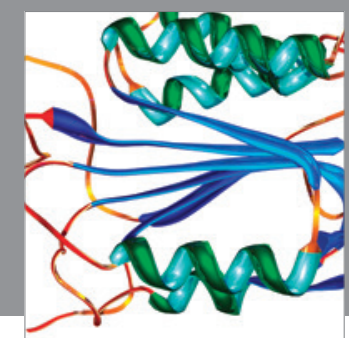

Disease Markers
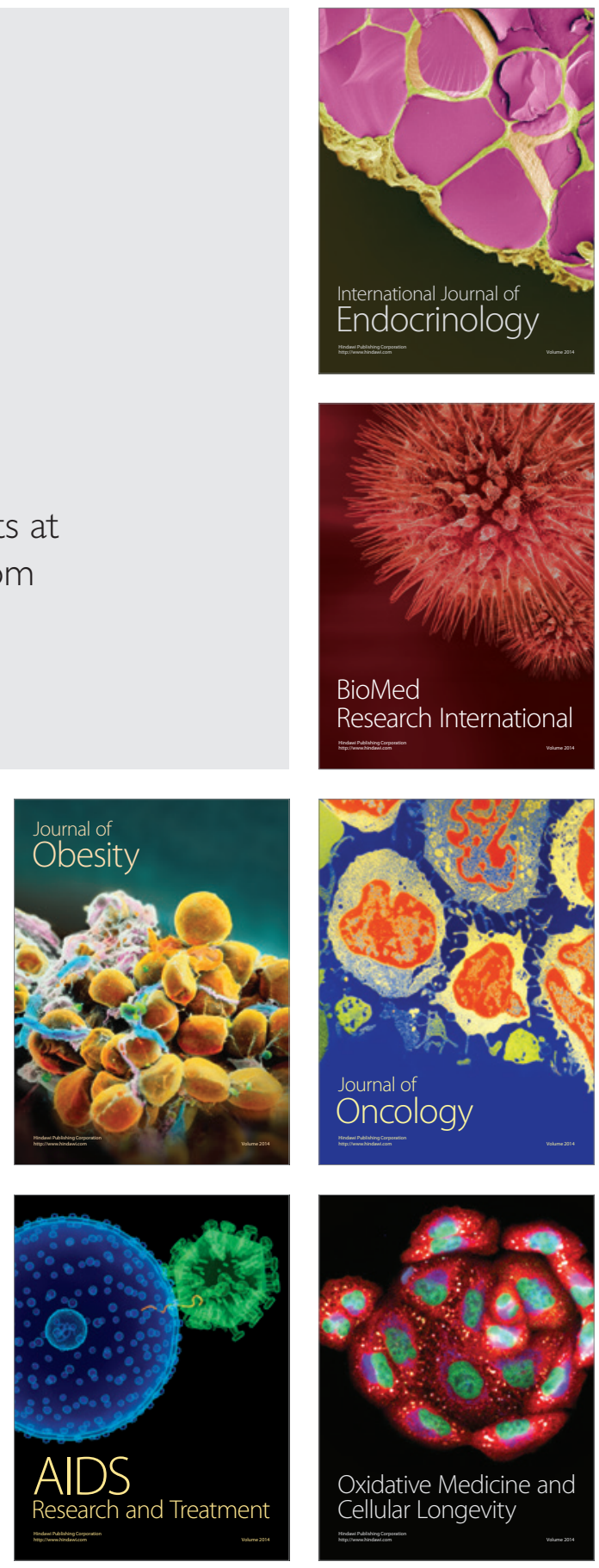